\title{
特定の基礎疾患をもたない心房細動に打ける脳塞栓発症因子 一臨床的ならびに病態生理学的検討一
}

\author{
寺井 敏 脇 理一郎 山口 武典* 熊谷 芳夫**
}

要旨：特定の基礎疾患の見られない心房細動における塞栓症の発症について，心エコー図な どを用いた病態生理, およびその臨床経過の特徵を検討した.

心房細動を有し，脳塞栓を発症したものと発症していないものの間に，左房径，左室拡張終 期容量, 左室駆出率などの差はみられなかった。このことから, 左房の拡大や左心機能の低下 は必ずしも塞栓症の発症には関与しないものと思われた。 また，今回対象とした脳塞栓例にお いて心内血栓はいずれにも認められなかったことなどから, 脳塞栓発症の情報を心エコー図か ら得ることは困難と思われた，脳塞栓例の臨床経過では，慢性持続性心房細動を有するものの $50 \%$, 発作性心房細動を有するものの $20 \%$ TIA を含めた脳梗塞の既往が認められた。このこ とから, 心房細動を有する患者で過去に TIA あるいは脳梗塞の既往のあるものは, それにつづ く脳塞栓が十分に起こりらるものと思われた。

Key words : cerebral embolism, echocardiography, idiopathic atrial fibrillation, preceding ischemic episode, systemic embolization

(脳卒中 $7: 330-335,1985$ )

はじめに

特定の基礎疾患の見られない心房細動は, 動脈硬化 あるいは高血圧がその原因とされ，75歳未満では $2 \%$, 75 歳以上では $5 \%$ を占めると報告されている ${ }^{1)}$ ，心房 細動には，慢性持続型を示するのと発作型を示すもの とがあり，後者に打いては，特定の基礎疾患を認めな い場合でも 4 年の間にその $10 \%$ は慢性持続型へ移行す るとされている2.

心房細動は，心拍出量の低下や運動能力の低下，そ して, 脳循環不全の原因となることの潘か, 塞栓症が その重大な合併症として注目されている。しかし, 基 礎疾患の明らかでない心房細動において，どのような 心房細動が塞栓症を起こしやすいのか, あるいは再発 を起こしやすいのかといらことは現在のところ全く不 明であり，また，心機能などから心房細動における塞 栓症発症の可能性についての病態生理を検討した報告 は今まで見られていない。

* 国立循環器病センター内科脳血管部門

** 現 千鳥橋病院内科
われわれは, 脳梗塞の発症および再発因子としての 心房細動において，心ェコー図などを用いたその病態 生理, 抒よび臨床経過に㧍けるその特徵を検討したの で，若干の文献的考察を加光報告する。

\section{対象および方法}

国立循環器病センター内科脳血管部門へ入院し, 脳 塞栓と診断され，かつその原因が基礎疾患の明らかで ない心房細動であると思われた 30 例を対象とした。こ のらち，慢性持続性心房細動を有するものは20例 (EC 群), 発作性心房細動を有するものは10例 (EP 群)で あった、コントロールとして, 特定の基礎疾患および 合併症のみられない慢性持続性心房細動を有するもの 68例 (C 群), 発作性心房細動を有するものを38例 ( $\mathrm{P}$ 群）を用いた。いずれの心房細動例においても，甲状 腺機能六進症などの内分泌疾患，そしてリウマチ性心 疾患や僧帽弁逸脱症などの弁膜症の合併例は含まれて おらず，また，心筇梗塞の合併例は㧍の扮のの対象か ら除外した。

これらの症例について心ェュー図より求めた左房 径, 左室拡張終期容量, 左室駆出率, および心電図所 
見や臨床経過などにつき比較検討した。なお， EC， EP， $\mathrm{C} ， \mathrm{P}$ の各群の平均年齢はそれぞれ，66.6 $65.5 \pm 10.5,62.4 \pm 7.9,62.5 \pm 7.8$ 歳（平均土標準偏 差）で，それぞれの間に有意差は認められなかった。 心ェコー図による計測は, Feigenbaumの方法に従 $($ (3), 左心機能の指標としての左室駆出率は, Teichholzの式を用いて左室抎張終期容量および収縮終期 容量を算出して求めた。また，心房細動例における計 測は先行 R-R 間隔が $800 \mathrm{msec}$ 以上の個所で行った ${ }^{4)}$. 装置は東芝製心断層装置 SSH-11A あるいはSSH-40 $\mathrm{A}$ を使用し， M モードはストリップチャートあるいは ポラロイドフィルムに記録した。

$\mathrm{EC}$ 群における心ェコー図は，1例を除き発症後 9 日目から 3 カ月目の間で記録されたものを用いた。 $\mathrm{EP}$ 群では, 発症前 2 力月と 3 力月に記録されたものがそ れぞれ 1 例, 発症当日が 1 例, その他は発症 16 日目以 降に記録されたものを用いた。 また心電図所見として は, 安静時の心電図における ST-T 偏位について検討 した．ST間部降下は標準四肢および胸部誘導におい て, horizontal 拉よび sagging type では $0.1 \mathrm{mV}$ 以上, junctional type では $\mathrm{PQ}$ 線から $0.15 \mathrm{mV}$ 以上の降下の 見られる場合にST降下 $(+)$ とし，その有無につき各 群間において $\chi^{2}$ 検定を用いて比較検討した。なお， EC 群および $\mathrm{EP}$ 群での心電図は, ともに発症前あるいは 発症 2 週以降に記録されたものを用いた。

\section{成 績}

\section{心エコー図に基づく各計測値}

各群に怙ける心ェコー図上り求めた各計測值は表 1 に示した通りである。まず，左房径については，慢性 持続性心房細動を有するもののなかで脳塞栓を起こし た群 (EC 群) と起こしていない群 (C 群) との間, お よび発作性心房細動を有するもののなかで脳塞栓を起 こした群 (EP 群) と起こしていない群 (P 群) との間 に明らかな差は認められなかった。しかし， C 群と $\mathrm{P}$ 群の比較検討では, C 群に沶いて明らかに左房径は大 であり $(\mathrm{p}<0.001), \mathrm{EC}$ 群と EP 群では， EC 群に左房 径が大である傾向が見られた。

左室拡張終期容量は各群間に全く差が認められな かった. 左室駆出率については, EC 群と C 群, および $\mathrm{EP}$ 群と $\mathrm{P}$ 群との間には有意差は認めなかった。しか し, C 群と $\mathrm{P}$ 群では, C 群において明らかに左室駆出 率が小さく $(\mathrm{p}<0.01), \mathrm{EC}$ 群と EP 群では, EC 群に 小さい傾向が見られた。
表 1 心ェコー図による各計測值

\begin{tabular}{|c|c|c|c|c|}
\hline & $\begin{array}{c}C \text { 群 } \\
(n=68)\end{array}$ & $\begin{array}{c}\mathrm{P} \text { 群 } \\
(\mathrm{n}=38)\end{array}$ & $\begin{array}{c}\mathrm{EC} \text { 群 } \\
(\mathrm{n}=20)\end{array}$ & $\begin{array}{c}\text { EP 群 } \\
(n=10)\end{array}$ \\
\hline $\begin{array}{l}\mathrm{LAD} \\
(\mathrm{mm})\end{array}$ & $\begin{array}{l}38.3 \\
\pm 7.4^{*}\end{array}$ & $\begin{array}{l}32.9 \\
\pm 6.3\end{array}$ & $\begin{array}{l}39.0 \\
\pm 8.2\end{array}$ & $\begin{array}{l}33.4 \\
\pm 6.9\end{array}$ \\
\hline$\underset{\left(\mathrm{cm}^{3}\right)}{\text { LVEDV }}$ & $\begin{array}{l}101.6 \\
\pm 29.2\end{array}$ & $\begin{array}{l}98.0 \\
\pm 26.3\end{array}$ & $\begin{array}{l}109.7 \\
\pm 40.8\end{array}$ & $\begin{array}{l}108.7 \\
\pm 23.5\end{array}$ \\
\hline E.F. & $\begin{array}{c}49.1 \\
\pm 13.5^{* *}\end{array}$ & $\begin{array}{l}56.5 \\
\pm 16.0\end{array}$ & $\begin{array}{l}55.2 \\
\pm 14.6\end{array}$ & $\begin{array}{l}61.6 \\
\pm 15.6\end{array}$ \\
\hline
\end{tabular}

* : p $<0.001 v s$ P 群

**: $\mathrm{p}<0.01$ vs $\mathrm{P}$ 群

LAD ; 左房径, LVEDV ; 左室拡張終期容量,

E.F. ; 左室駆出率

表 2 心房細動の罹病期間

\begin{tabular}{c|c|c}
\hline & 罹 病 期 間 & mean $\pm \mathrm{SE}$ \\
\hline $\begin{array}{c}\mathrm{C} \text { 群 } \\
(\mathrm{n}=62)\end{array}$ & $1 \sim 300$ 力月 & $62.4 \pm 8.2$ 力月 \\
\hline $\begin{array}{c}\mathrm{P} \text { 群 } \\
(\mathrm{n}=35)\end{array}$ & $0.8 \sim 240$ 力月 & $69.2 \pm 18.3$ 力月 \\
\hline $\begin{array}{c}\mathrm{EC} \text { 群 } \\
(\mathrm{n}=20)\end{array}$ & $* \sim 384$ 力月 & $125.5 \pm 28.4$ 力月 \\
\hline $\begin{array}{c}\mathrm{EP} \text { 群 } \\
(\mathrm{n}=10)\end{array}$ & $* \sim 96$ 力月 & $19.2 \pm 10.0$ 力月 \\
\hline
\end{tabular}

* : 入院時に初めて心房細動を指摘,

$\dagger: \mathrm{p}<0.05$ vs C群拈よび $\mathrm{EP}$ 群

$\mathrm{EC}$ 群の罹病期間は C 群扢よび $\mathrm{EP}$ 群に比べて明らかに長 い

このように，心ェコー図より求めた各計測値では, 左房径执よび左室駆出率において C 群と $\mathrm{P}$ 群に有意 差が見られ，同様の傾向が EC 群と EP 群の間に認め られたが，C群と EC 群および P 群と EP 群の両群間 には, 左房径, 左室拡張終期容量および左室駆出率に おいて，いずれも有意差は認められなかった。な抏， 今回対象とした脳塞栓例には，いずれの例にも心内血 栓は認められなかった。

\section{心房細動の罹病期間}

初めて動悸や脈の不整を自覚した時, あるいは心電 図上心房細動を初めて指摘された時を仮に心房細動の 発症時とし，その罹病期間について各群間での比較検 討を行った.なお， C 群の 6 例, $\mathrm{P}$ 群の 3 例では罹病期 間の判定が困難であったため, 比較の対象から除外し た. C 群と $\mathrm{P}$ 群，执よび $\mathrm{P}$ 群と $\mathrm{EP}$ 群の間には有意差 が見られなかったが，C群と EC 群，および EC 群と $\mathrm{EP}$ 群の間では，EC群の羅病期間が有意に長かった (表 2 ). また，入院時に初めて心房細動を指摘された ものが EC 群では20例中 4 例 (20\%), EP 群では，10 
表 3 脳梗塞, TIA 抢よび他臓器塞栓症の入院前で の既往, 拈よび入院後での再発の頻度

\begin{tabular}{|c|c|c|c|c|c|c|}
\hline & \multicolumn{3}{|c|}{$\mathrm{EC}$ 群 $(\mathrm{n}=20)$} & \multicolumn{3}{|c|}{$\mathrm{EP}$ 群 $(\mathrm{n}=10)$} \\
\hline & 脳梗塞 & TIA & $\begin{array}{l}\text { 他臓器 } \\
\text { 塞 栓 }\end{array}$ & 脳梗塞 & TIA & $\begin{array}{l}\text { 他臟器 } \\
\text { 塞 栓 }\end{array}$ \\
\hline 入院前 & $\begin{array}{c}5 \\
(25 \%) \\
\end{array}$ & $\begin{array}{c}7^{*} \\
(35 \%) \\
\end{array}$ & 不 詳 & $\begin{array}{c}2 \\
(20 \%) \\
\end{array}$ & $\begin{array}{c}1 \\
(10 \%) \\
\end{array}$ & 不 詳 \\
\hline 入院後 & $\begin{array}{c}3 \\
(15 \%)\end{array}$ & $\left(\frac{1}{5 \%}\right)$ & $\begin{array}{c}2^{* *} \\
(10 \%)\end{array}$ & $\begin{array}{c}2 \\
(20 \%)\end{array}$ & $\begin{array}{c}0 \\
0 \%\end{array}$ & $\begin{array}{c}1 \\
(10 \%)\end{array}$ \\
\hline
\end{tabular}

*脳梗塞と TIA の合併例は 2 例みられた

**脳梗塞と他臓器塞栓の合併例は 1 例みられた

例中 6 例（60\%）に認められた。

\section{安静時心電図上の ST-T 偏位}

$\mathrm{ST}$ 降下 $(+)$ は C 群68例中 10 例, P 群38例中 6 例, $\mathrm{EC}$ 群 20 例中 10 例, そして $\mathrm{EP}$ 群 10 例中 4 例に認められ た。これらの頻度は $\mathrm{EC}$ 群で最も高く, C 群との差は統 計学的に有意であった $\left(\chi^{2}\right.$ 検定, $\left.\mathrm{p}<0.005\right)$.

\section{脳塞栓群の臨床経過}

$\mathrm{EC}$ 群と EP 群において, 入院前後での脳梗塞, TIA あるいは他藏器塞栓症の有無拈よびその頻度について 検討した(表 3 )。入院前に脳梗塞，TIA を経験してい たものは，EC 群では 20 例中それぞれ 5 例 (25\%)， 7 例 (35\%) であるのに対し, EP 群では10例中 2 例 （20\%）に脳梗塞， 1 例（10\%）に TIA の既往があっ たにすぎなかった。なお，両群とも他臟器塞栓症の既 往は明らかでなかった。 入院後では, EC 群において20 例中 3 例 (15\%) 飞脳梗塞， 1 例（5\%）に TIA の再 発が， 2 例 (10\%) に他藏器塞栓症が見られた。一方, $\mathrm{EP}$ 群では10例中 2 例 (20\%) に脳梗塞の再発が， 1 例 （10\%）に他臟器塞栓症が見られた。

\section{考案}

心房細動における重大な合併症の 1 つに塞栓症が挙 げられるが，特定の基礎疾患を認めない心房細動例で は，その約 $8 \%$ に塞栓症が見られると報告されてい

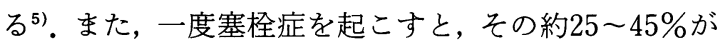

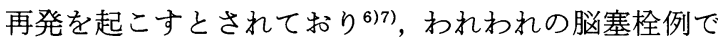
も慢性持続性怙よび発作性心房細動を有するもので は，ともに，TIA も含めるとその $30 \%$ に院後での再 発が認められている。

基礎疾患の見られない心房細動についての病理学的 検討によると，罹病期間の長い程，左房容積の増大お よび左房筇線維の消失を伴い，また左心耳内血栓の合 併率が高く，塞栓症発症の危険が増大すると報告され
ている ${ }^{8)}$ 。器質化した血栓が塞栓症の原因となるか否 かは議論のあるところであり，かつ塞栓症の例に拈い て左房内血栓を認めない例も比較的多いことょり, 単 純に左房内血栓の存在と塞栓症とを関係づけることは 出来ないものと思われる。しかし, 塞栓症例では非塞 栓症例に比べ左房内血栓の合併が多いとの報告や99, 左房内血栓の存在する例に塞栓症が多く見られるとの 報告があり ${ }^{910)}$, 左房内血栓の有無の確認は塞栓症予 防の意味で重要と思われる。左房内血栓は壁在血栓と 左心耳内血栓に分けられ，それぞれ局所的な心内膜炎 や血液の左房内での停滞が原因とされているが，弁膜 症のない心房細動例では左心耳内血栓の合併が多 (10). 左房内血栓の非観血的な診断法として断層心土 コ一図が広く使用されているが，左心耳内血栓の検出 はビームの特殊性などから非常に困難とされ，また， 肺気腫のある患者や骨化の六進している老人での検索 が不可能であることより，断層心エコー図による左房 内血栓の検出には限界があると考兄ているものもあ る ${ }^{11}$. われわれの塞栓症例でも, 心房細動例のみに限る と左房内血栓は 1 例も見つかっていない，現在最も検 出率の高い検査としてコンピューター断層撮影による 横断面断層が挙げられているが(11)12)，基礎疾患の見ら れない心房細動を有する患者全例に施行することはむ ずかしく,その適応についての検討が必要と思われる。 左房拡大や左心機能の低下は心腔内に血液うっ滞な ぞを生じ血栓形成を起こしやすいものと思われる。心 エコー図を用いたわれわれの検討の結果，塞栓症を発 症していない慢性持続性心房細動群では発作性心房細 動群と比べ明らかに左房径が大きく，かつ左室駆出率 は低下していた。塞栓症を発症した慢性持続性心房細 動群と，発作性心房細動群との間にも同様の傾向が見 られたが，慢性持続性および発作性心房細動を有する 塞栓症例と非塞栓症例の間には, 左房径や左室駆出率, そして左室拡張終期容量に有意差が見られなかった。 また，発作性心房細動を有する塞栓症例では，その左 房径, 左室拡張終期容量, 左室駆出率のいずれもが正 常範囲内であった。これらのことから，左房や左室の 拡大，扣よび左心機能低下は必ずしも塞栓症の発現に 関与しないものと思われた。

心房細動の罹病期間と心房筋の障害との間には，あ る程度の相関が見られると報告されている ${ }^{11}$. 慢性持 続性心房細動を有する塞栓症例では, , 非塞栓症例に比 べて罹病期間が有意に長いことから，塞栓症を発症し たものでは左房筋線維の障害が進行して招り，左房内 
に血栓を形成しやすい可能性もある。しかし，特に基 礎疾患の見られない発作性心房細動では心房筋の障害 は少ないものと考えられ，また発作性心房細動を有す る塞栓症例での罹病期間は, 持続性心房細動を有する 塞栓症例と比べ有意に短かく, かつ, 半数以上が塞栓 症発症時に初めて心房細動を指摘されている. これら のことから, 罹病期間の長さや左房等線維の障害は塞 栓症発症の 1 つの因子とはなっても, 必ずしも極めて 重要な位置を占めているとは考学にくい。

慢性持続性心房細動を有する塞栓症例では，20例中 10例 (50\%) 飞安静時の心電図上, 虚血性 ST 降下が見 られ, その頻度は非塞栓症例に比べて明らかに大で あった。しかし, 発作性心房細動を有するものでは, 塞栓症例と非塞栓症例との間に差が見られなかった。 このことから心電図上の ST-T 偏位の存在も必ずし も塞栓症発症の指標之はならないものと思われる。乙 かしながら安静時での虚血性 ST 降下の所見は心室筋 に小壊死や線維化などの器質的変化がすでに生じてい ることを示していると言われていることから ${ }^{13)}$, ST-T 偏位をきたすような慢性持続性心房細動では, 心室内 血栓を形成しやすいという可能性を否定できない。

確かに, 長期間にわたる持続性心房細動の存在は, 左房の抬張, 左房筋の障害をきたし, ひいては左室の 拡大や左室収縮能の低下, 心室筋の障害などを惹起す るので, 何らかの形で血栓形成に関与するであろうこ とは否定できない。したがって，これらが心房細動例 に打㤝塞栓症発症の大きな因子の 1 つであることに は異論はないものと思われる。しかし，それだけでは 心房細動に拈ける塞栓症をすべて説明出来ず，何か他 の因子の関与も考えられる.

血流速度の速い動脈系での血栓形成に扮いては，血 小板系の関与が重要とされており, 高いずり速度など がその活性化の因子とされている4).心房細動では, 収 縮期に打ける左室から左房への逆流が存在すること が，実験的および臨床的にも示唆されていることか $5^{15116)}$, 左房内血栓形成の原因としての血流因子の関 与も考えられるが, 今のところ推論の域を出ない.

今回われわれは心エコ一眓を用いて，特定の基礎疾 患の認められない心房細動における塞栓症発症の病態 生理学的因子の解明を試みたが, 塞栓症を発症したも のと, 発症していないものの間に左房径やその他の心 機能に明らかな差を見出すことはできなかった。をた， 心ェコー図による左房内血栓の検出能力には限界があ るとされていること, 赤血球凝集のような機序がその
原因とされている流動エコー（もやもやエコー）につ いても，血栓形成との間に明らかな対応が認められて いないことなどを合せ考劣ると年18), 現時点では塞栓 症の発症への情報を心土コー図から得ることは困難で あると思われる。

臨床経過では, 慢性持続性および発作性心房細胞を 有する脳塞栓例において, TIA を含めた虚血性脳血管 障害の既往が多く認められることが注目される。特に, TIA の既往は慢性持続性心房細動を有するものでは その $35 \%$ ， 発作性心房細動を有するものではその 10\%に見られて拈り,この TIA は心房細動による塞栓 症が原因である可能性が強い。このことょり，心房細 動を有するもので以前にTIA も含めた虚血性脳血管 障害のあるものでは, これにつづく塞栓現象の再発が 十分に予測されるため, 再発予防の目的で早めに抗血 小板療法あるいは抗凝血剂療法の開始を検討する必要 があるものと考觉られる。

稿を終るにあたり，心エコー図の分析の機会をお与兄い ただいた, 内科心臟部門棉原博部長, ご助言をいただいた同 朴永大先生に深謝いたします。尚本研究の一部は厚生省循 環器病研究委託費 $(59$ 公一 3 , 脳梗塞の二次予防を目的とし た臨床疫学的研究) の援助によりなされた。

\section{文献}

1) Campbell A, Carid FI, Jackson TEM: Prevalence of abnormalities of electrocardiogram in old people. Br Heart J 36 : 1005-1011, 1974

2) Takahashi N, Seki A, Imataka $K$, et al: Clinical features of atrial fibrillation: An observation of 94 patients. Jpn Heart J 22 : 143-149, 1981

3) Feigenbaum H: Echocardiography, 3nd Edition. Lea and Febriger. Philadelphia, 1981

4) Boudoulaus H, Levis RP, Sherman JA, et al: Systolic time intervals in atrial fibrillation. Chest $74: 629-634,1978$

5) Wolf PA, Dawber TR, Thomas E Jr, et al: Epidemiologic assessment of chronic atrial fibrillation and risk of stroke: The Framing. ham study. Neurology 28: 973-977, 1978

6) Wolf PA, Kannel KB, McGee DL, et al: Duration of atrial fibrillation and imminence of stroke: The Framingham study. Stroke $14: 664$ -667, 1983 
7) Darling RC, Austen WG, Linton RR, et al : Arterial embolism. Surg Gynecol Obstet 124 : 106-114, 1967

8) Davies MJ, Pomerance A : Pathology of atrial fibrillation in man. Br Heart J 34: 520-525, 1972

9) Hinton RC, Kistler JP, Fallon JT, et al : Influence of etiology of atrial fibrillation on incidence of systemic embolism. Am J Cardiol $40:$ 509-513, 1977

10) Aberg $\mathrm{H}$ : Atrial fibrillation. 1. A study of atrial thrombosis and systemic embolism in a necropsy material. Acta Med Scand 185: 373 $-379,1969$

11）島田悦男, 浅野 浩, 倉沢忠弘ら：左房内血栓の臨 床的検討，とくに心ェコー図とCTscan との比較 検討. J Cardiography $11: 933-944,1981$

12）稲垣義明, 吉田秀夫：心房内血栓症. 綜合臨床 $30: 2713-2718, \quad 1981$
13）金沢知博, 小野幸彦：心電図- $\mathrm{ST} \cdot \mathrm{T}$ 偏位. Medicina 19:628-631, 1982

14）磯貝行秀, 池本 卓: 血流之血栓. 内科 54 : 418-420, 1984

15) Naito M, David D, Michelson EL, et al: The hemodynamic consequences of cardiac arrhyth. mias : Evaluation of the relative roles of abnormal atrioventricular sequencing, irregularity of ventricular rhythm and atrial fibrillation in a canine model. Am Heart J 106 : 284-291, 1983

16) Samet $P$, Bernstein $W$, Levine $S$ : Significance of the atrial contribution to ventricular filling. Am J Cardiol, 15 : 195-202, 1965

17）朴 永大, 長崎孝太郎, 別府慎太郎5：心筋梗塞拈 よび拡張型心筋症における左室腔内流動エコーに ついて。超音波医学 $11: 68-76,1984$

18）別府慎太郎, 上岡政重, 榊原 博5：左房内流動工 コーの臨床面からの検討. 日超医論文集 41 : $339-340,1982$ 


\begin{abstract}
Factors for cerebral and systemic embolization in idiopathic atrial fibrillation -Clinical and pathophysiological approach-

\author{
Satoshi Terai, M.D., Riichiro Waki, M.D., Takenori Yamaguchi, M.D.* \\ and Yoshio Kumagai, M.D.** \\ ${ }^{*}$ Cerebrovascular Division, Department of Internal Medicine, National Cardiovascular Center \\ ** Division of Internal Medicine, Chidoribashi Hospital
}

In attempt to elucidate the factors which promote cerebral and systemic embolization in idiopathic atrial fibrillation, cardiac pathophysiology was studied in patients with cerebral embolism due to atrial fibrillation (af), by using two-dimensional echocardiographic technique. Difference in clinical features of cerebral embolism between patients with persistent af and with paroxysmal af was also investigated.

Left atrial diameter (LAD) and left ventricular dimension were measured by echocardiography, and end-diastolic volume (LVEDV) and ejection fraction (EF) as a parameter of left ventricular function were calculated from the results of above measurements.

The embolic group was consisted of 20 patients with chronic persistent af and 10 patients with paroxysmal af. One hundred and six patients without having systemic embolization were used as controls, of whom 68 were with persistent and 38 were with paroxysmal af.

There were no significant differences in LAD, LVEDV and EF between embolic and control groups. Differences were found only in LAD and $\mathrm{EF}$ between patients with persistent af and paroxysmal af of the control group; i.e. larger $\mathrm{LAD}$ and lower EF in persistent af than in paroxysmal of of the controls. Besides, intracardiac thrombus was not detected by echocardiography in the embolic group.

From the results of the present study, it was suggested that left atrial enlargement and hypofunction of the left ventricle did not necessarily promote systemic embolization in patients with idiopathic af, and it appeared to be difficult to obtain a cue for embolization from the echocardiographic findings.

With regard to the preceding ischemic episodes in the embolic group, $50 \%$ of those with persistent af had experienced previous ischemic cerebral events including TIA, and $20 \%$ of the embolic patients with paroxysmal af had the history. Thus, it is necessary to provide a preventive measure against further ischemic stroke, when the patient with idiopathic af having a history of ischemic episodes is encountered.

(Jpn. J. Stroke 7: 330-335, 1985) 